\title{
The rhetorical purpose of Israel's notion of the 'whole body' as the ideal body in the psalms: A comparative study of selected psalms from four different genres
}

\begin{abstract}
Authors:
Cornelius J.J. Wessels ${ }^{1}$

Johan H. Coetzee ${ }^{1}$

Affiliations:

${ }^{1}$ Department of Religion

Studies, University of

Johannesburg, South Africa

Correspondence to:

Johan Coetzee

Email:

johanc@uj.ac.za

Postal address:

PO Box 524, Auckland Park

2006, South Africa

Dates:

Received: 13 July 2012

Accepted: 21 May 2013

Published: 31 July 2013

How to cite this article: Wessels, C.J.J. \& Coetzee, J.H., 2013, 'The rhetorical purpose of Israel's notion of the "whole body" as the ideal body in the psalms:

A comparative study of selected psalms from four different genres', Verbum et Ecclesia 34(1), Art. \#766, 6 pages. http://dx.doi. org/10.4102/ve.v34i1.766

\section{Copyright:}

(C) 2013. The Authors.

Licensee: AOSIS

OpenJournals. This work

is licensed under the

Creative Commons

Attribution License.
\end{abstract}

Read online:

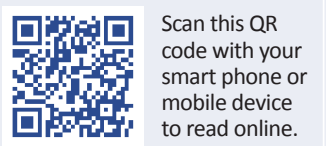

The authors of the psalms implemented body rhetoric, especially the notion of the "whole body' $^{\prime}$ as the ideal body, in the various genres of psalms, with specific purposes in mind. The whole body as ideal body served as a defining paradigm within the ancient Israelite culture. In this article, the relationship between the embodied God-concept, the ideal societal body and the individual body is investigated in order to determine the purpose of the implementation of this ideology of whole-bodiedness in selected psalm genres. In Psalm 2, the political body as cultural construct plays a prominent role in directing the individual to think of the body in a specific manner. In Psalm 6, the 'broken body' drives the lamentation of the psalmist towards recovery. Psalm 29 reflects the poet's ability to sketch, in hymnic-embodied language, God's relationship with his creation and his people and the poet's worship for God's fullness of existence and activity. Psalm 32, as a psalm of thanksgiving, pictures God as the whole body in terms of the saviour, protector and healer of the broken (sinful) body.

\section{Introduction}

Ever since the Cartesian dichotomy between body and mind infiltrated Western thinking and dominated perceptions regarding human beings, the body has been neglected. This is because reason is believed to be 'abstract and transcendent ... not tied to any bodily aspects of human understanding' (Johnson 1987:xiv). However, Leder (1990:1) argues that the human body is the centre of everything that we perceive, and it is also the centre of all our responses to the world, within and outside of our bodies. It is for this reason that Johnson (1987:xiv) states that it is of great importance that the body is brought back into the mind and that a viable, alternative approach to humans and their encounter with their environment be followed. This statement, however, creates a paradox for any Christian and Jewish studies of the Old Testament (Hebrew Bible) for the bodily perspectives of ancient Israel are to a large extent unknown to us. In spite of this gap in knowledge, it is possible to learn about the bodies of ancient Israel through the study of the rhetoric pertaining to the body in the Bible. This is because the body is deeply symbolic in human culture and is the means by which people and communities express themselves (Berquist 2002:5; Isherwood \& Stuart 1998:10). Therefore, language as such is embodied, and by studying the language and bodily rhetoric of a specific culture, we can learn much about ancient Israel's notions of the body.

In the Old Testament Psalter, we find descriptions of ancient Israel's various life situations, a large range of aspects relating to Israel's relationship with God and Israel's perspectives concerning creation, the animal world, the surrounding nations and the Kingdom of God itself (Eaton 2005:3). It is evident that the body must have played a vital role in Israel's paradigms concerning the world around them and their relationship with God. In the different genres of the psalms, we also come across a variety of emotions that influenced metaphorical expressions about the body and God. To study these psalms from a bodily point of view, whilst relating these emotions to the body itself, will shed light on the embodied relationships between the supplicants and God and the role played by the notion of the 'whole body' in these relationships.

Of course, the authors of the Bible also projected the cultural model of the Israelite human body onto the sphere of the divine (Malina 1993:82). God is understood in terms of the human body, especially to underscore the differences between God and humans (Malina 1993:78). God is the complete, whole model of the human body that is in total harmony with everything and everybody.

Thus in the Psalter, we find various bodily perspectives from ancient Israel. The psalmists implemented body rhetoric relating to the notion of the 'whole body' as the ideal body in the 
various psalm genres with specific purposes in mind. This ideal-body motif of the 'whole body' implied the healthy, intact, male body serving as 'a metaphorical representation of how society should be organized' (Berquist 2002:15). The 'whole body' existed in an individual sense and in a corporate sense and finds itself in consistent dialogue with Yahweh as the 'super model' of the complete body.

The article will illustrate this notion through the investigation of four different psalms from four different genres, namely Psalms 2, 6, 29 and 32. Thus, the four genres under discussion will be royal psalms (Ps 2), individual psalms of lament (Ps 6), hymns (Ps 29) and psalms of individual thanksgiving (Ps 32). The claim is not that the four psalms are completely representative of the four genres and of Israel's thinking but rather that they are illustrative of Israel's embodied thinking.

\section{An analysis of Psalms 2, 6, 29 and 32}

The first two psalms will be dealt with more briefly due to space restrictions, whilst Psalm 29 and Psalm 33 will be explored in more detail.

\section{Exposition of the psalms}

Robbins' (1996a, 1996b) socio-rhetorical approach to sacred texts has been implemented to explore the selected psalms. Lawrence (2005:14) states that a cross-field study, incorporating anthropology and biblical studies, can help to minimise the cultural indifferences within hermeneutics. However, such a combination of fields is not the only combination that may contribute to a more accurate interpretation of the psalms. Socio-rhetorical interpretation is a combination of rhetoric, modern anthropology and sociology (Robbins 1996a:1) with its application in biblical science, which makes it the ideal method of interpretation for the purposes of this research. Robbins (1996a:1) states that the best way to describe the socio-rhetorical model of interpretation is by explaining each part of the word or phrase 'socio-rhetorical'. The 'socio' refers 'to rich resources of modern anthropology and sociology that socio-rhetorical criticism brings to the interpretation of a text'. The term 'rhetorical' refers to 'the way language in a text is a means of communication among people' (Robbins 1996a:1). Rhetorical analysis and interpretation give special attention to 'the subject and topics a text uses to present thought, speech, stories, and arguments' (Robbins 1996a:1). Thus, Robbins' method can be seen as a holistic approach to the interpretation of a given text and, in this case, to explore embodiment in the rhetoric of the chosen psalms.

\section{Psalm 2}

Psalm 2 forms part of the genre of royal psalms. Eaton (2005:18) describes a royal psalm as a psalm that contains oracles and prayers in various patterns from a variety of situations but having a common origin in outstanding royal ceremonies. Psalm 2 falls into this category. Originally, it was probably part of the liturgy celebrating the accession to the throne of the king in pre-exilic Jerusalem and of an annual ceremony re-enacting the coronation and confirming the vital place of the king in the life of the community (Davidson 1998:14).

We find that, throughout Psalm 2, the psalmist implements rhetoric concerning the whole body as an ideal body. The ideal, whole male body is illustrated in the anointed king who is contained within the fixed boundaries of his Judaic kingship. However, the king represents the super-model, Yahweh, who empowers him to reign over the entire world.

The maintenance of the boundaries of the kingdom body is imperative to its wholeness. The head (the king) of the kingdom (political) body is anointed, which bestows Yahweh's protection and authority upon the kingdom body.

In Psalm 2, we find that Yahweh is viewed as the divine king. As the ideal body, his interaction with humankind is complete and in harmony, making him the ideal whole body. Yahweh's ideal body is extended through the Israelite king upon earth. In particular, the father-son relationship between God and the king (vv. 7b, 12a) is of interest with regards to the family relationships in Israel's culture as background.

Thus, the specific rhetorical purpose of the implementation of the concept of the 'whole body' as the ideal body is to affirm Yahweh's and his king's authority for the implied cultic audience and to warn the foreign nations against the threat they pose to the wholeness of the Israelite kingdom body.

\section{Psalm 6}

Psalm 6 forms part of the genre of psalms of individual lament. This genre is the most frequently found in the Psalter (Westermann 1980:53). It is normally used in worship where a character in the given psalm comes with a troubled heart to the place of worship and pours his or her heart out and then receives confirmation that God had indeed heard the lamentation (Westermann 1980:54). Kraus (1972:48) relates this lament to a situation where the suppliants find themselves in a situation of severe illness. The psalm serves as a serious request to God for healing. According to Leder (1990:77), pain exerts a telic demand upon the human body, which is fundamental to the outcry to God for healing. Bodily healing in itself is an experience of 'whole-bodiedness' but also of the healing of the relationship between God and the societal body (Berquist 2002:11, 15, 22, 28).

In Psalm 6, we find that the psalmist as an 'un-whole body' pleads with Yahweh due to the state of personal anguish and suffering implied in 'bones' (v. 3[2])1 ${ }^{1}$, 'soul' (4a[3a]) and 'eyes' (8a[7a]). The psalmist's community perceives him as 'un-whole', which implies that he presents a threat to the wholeness of the community and the society (vv. 8b, 9 [7b-8]). The psalmist experiences persecution from enemies in the community. However, he receives assurance of his wholeness from Yahweh (v. 10[9]) but not from his peers. For this reason, the psalmist demands that his persecutors depart from him.

1.The numbering of the verses of the Hebrew version and the translated versions differ. The numbering of the translation is displayed in brackets. 
For the author, Yahweh's anger and wrath (v. 2 [1b]) as opposed to his mercy (vv. 3, 5 [2, 4]) and his hearing and acceptance of the supplicant's plea (v. 10[9]) form the two extreme opposites of his wholeness and completeness based on human bodily and emotional experience. The faculty of 'hearing' distinguished Yahweh from the other Near-Eastern gods (Schroer \& Staubli 2001:130-131). This was the main characteristic of the relationship between Yahweh and the nation of ancient Israel. Hearing goes hand-in-hand with understanding (Schroer \& Staubli 2001:125). Therefore, if Yahweh hears a person's pleas, it suggests a personal God who understands a person's circumstances.

By asking Yahweh to turn to him (v. 5 [4]), the psalmist is asking Yahweh to turn his face to him. 'The human head has always been regarded as the top of the hierarchy of body parts, and therefore represents, as pars pro toto, the whole person' (Schroer \& Staubli 2001:83). The face of Yahweh was synonymous with his presence, his blessings and prosperity. If the psalmist is no longer part of Yahweh's household, he will not receive the blessings and prosperity required to have a good life. Being separated from Yahweh's presence results in death, hence the reference to Sheol (v. 6 [5]). Kraus (1992:165) calls it 'spiritual death', which refers to a state of complete 'un-wholeness'.

According to Malina (1993:77), the biblical authors described Yahweh in terms of analogies based on humans and human behaviour. However, he is the 'ideal body', the supermodel. Therefore, Yahweh functions from the ideal body in comparison to the psalmist's un-whole body. The psalmist therefore highlights the difference between his broken body and the whole body of Yahweh through his bodily reference to Yahweh whilst striving towards wholeness himself.

In summary: In Psalm 6, we find that embodied concepts of Yahweh are mentioned in order to illustrate the differences between Yahweh and the human characteristics in the psalm. Yahweh is the ideal whole body and is therefore capable of disciplining the psalmist (v. 2[1b]) and reaffirming his wholeness in the psalm. It is to Yahweh's wholeness and completeness that the supplicant can appeal for reincorporation into the personal and societal state of wholebodiedness.

The psalmist's rhetorical purpose underlying the implementation of the concept of the whole body as the ideal body in Psalm 6 is to stress his own bodily brokenness and un-wholeness in his situation of distress in contrast to Yahweh's ideal and perfect wholeness. It is on the basis of this juxtaposition, driven by the telic demand of his body for restoration, that he appeals for personal wholeness. Only Yahweh can change his fate so that he can become whole again, to the shame of his enemies.

\section{Psalm 29}

Hymns such as Psalm 29 are songs that glorify God, not only for a single deed but for the fullness of his existence and activity (Eaton 2005:18; Westermann 1980:26), that is, for his complete wholeness as depicted by his kingship in this psalm. Kraus (1972:234) interprets Psalm 29 as a 'Theophaniepsalm' where God appears in a theophany during a cult festival. The psalm presents itself as an outstanding vehicle for studying the embodiment of God in relationship with nature.

The worshiping of Yahweh plays an important role in Psalm 29. Various embodied concepts of Yahweh are mentioned in verses $1-5$ and 5-7 in which the psalmist describes Yahweh's voice. The genre serves the purpose of glorifying Yahweh by implementing rhetoric about the body.

The cultural intertexture found in the psalm relates directly to the bodily rhetoric of ancient Israel as the psalmist is part of the people of God (Israel), which forms one 'social body' with the heavenly beings, reflecting the whole body of God. This social body reflects Yahweh's ideal whole body, and it is for this reason that Yahweh should be praised, that is, because he is the true and ideal whole body. Relationships and roles observable in the psalm include the relationship between Yahweh, the beney 'elîm [sons of God] (v. 1) and the 'am [people] (v. 11). However, the only 'social' relationship observable is that between the 'am and the beney'elim.

The expression 'amo, [his people] found in verse 11, refers to Israel, Yahweh's people. Kraus (1992:68) states that this expression had cultic significance. He points out that the expression specifically refers to the cultic community gathered on Zion to praise God in his presence. However, it also refers to the community of faithful believers, wherever they may be (cf. Ps 28:8-9). The social relationship observable in Psalm 29 as a cultic psalm is thus a relationship between the members of the cultic community and the heavenly beings mutually partaking in the worship of Yahweh.

Peels (2001:185) maintains that Yahweh's heavenly and earthly kingdoms should not be viewed in juxtaposition but should instead be seen as complementary. In the context of the cultic worship of Yahweh, the community gathered on Zion metaphorically represented and paralleled the congregation of heavenly beings in the heavenly world who praised Yahweh (Kraus 1992:68). Kraus (1992:68) states that this worship in Zion functions as an 'antiphonal choir ... [in which] the whole world of heaven and earth is caught up in the praise of God'. As such, the worshipping earthly household is seen as 'equal' and parallel to the heavenly household in worship of Yahweh.

It is only within the context and ordinance of Yahweh that humankind carries any significance (Weiser 1962:114). Support for this view can be found in Psalm 8 as Kraus (1992) states:

[i]n relation to the higher, divine world, mankind is to be seen and understood, not through presumptuous and mythological motivated assertions, but in a manner that corresponds to the ordinance of Yahweh. (p. 149)

This ordinance is found in nature in general (vv. 3-9b) as well as in God's temple (v. 9c). Therefore, in the context of the 
worship of Yahweh, the heavenly beings and the people of God have the same social role to fulfil, that is, the worship of Yahweh. Thus, in the context of worship of Yahweh, it can be concluded that the 'amo and the beney 'elim form one 'social body' (Lawrence 2005:27).

Leder (1990:166) argues that, through an aesthetic experience, a person can become aesthetically absorbed into one's surroundings and can become interconnected with other bodies (Leder 1990:165). This does not refer to a physical body but refers instead to a feeling of interconnectedness with one's surroundings and an experience in which one feels a sense of oneness with surrounding things (Leder 1990:165). Leder further explains that, through an aesthetic experience, a person becomes aware of previously unnoticed surroundings and can become absorbed in these. Whilst absorbed in this experience, concepts of time, space and boundaries are shifted (Leder 1990:166). The person is absorbed into and becomes one with his or her surroundings.

The psalmist calls upon the 'am and the beney 'elim to praise Yahweh. Through his aesthetic and spiritual (cultic) experience of worshipping Yahweh, the author experiences one-bodiedness with the beney 'elim and 'am. Through the worship in the temple (v. 9), the psalmist suddenly becomes aesthetically absorbed into his surroundings. This shifts his perceptions of his boundaries, time and space. He envisions himself praising Yahweh together with the beney 'elim in heaven. Through this experience of absorption, the psalmist thus becomes one body with his fellow cultic members and the heavenly beings. It is in this sense that the heavenly beings and the cultic community of ancient Israel come together to form one social body. The temple on Zion was viewed as Yahweh's earthly throne and the place where the heavenly and earthly spheres meet (Schäder 2010:139) and form one body.

The psalmist states that Yahweh should be 'worshiped in the splendour of holiness' (v. 2b). According to Kraus (1992), Yahweh's holiness:

\footnotetext{
... does not involve contrasting extremes such as the polarity between God and world or creator and creation but, as is shown by context, our attention is called to the way in which majesty permeates the whole earth ... It is God's absolute will to bring about recognition of his kingly authority among his people, and among the people of the world. (p. 41)
}

This means that the holiness of Yahweh comes from his royal perfection as king, worthy of adoration because his divine power shines forth in glory that fills the world (Kraus 1992:41-42).

In addition, Kraus (1992:41) argues that Yahweh's holiness is also related to his perfection. Berquist (2002:19) in this regard states that ancient Israel's perception was directly influenced by their rhetoric concerning the ideal body. To the ancient Israelites, the ideal body was one that lacked nothing (Berquist 2002:19). As a result, the embodied perception of God would be that of a kingly body lacking nothing. Thus,
Yahweh's kingly body, his reign as perfect king, will always be perceived as 'whole'.

Yahweh is viewed as the true 'ideal whole body' in Psalm 29. As the ideal whole body, the 'am, the beney 'elim and nature should submit to his authority and glorify him. The psalmist recognises Yahweh's might through the theophany of the storm, and because nature is also part of Yahweh's ideal body, it duly submits to his authority and glorifies him. As part of Yahweh's ideal whole body, the psalmist receives Yahweh's blessing and his peace. His self-revelation is greater than nature and those that oppose him. This is illustrated through the theophany of the storm. The embodied concepts of Yahweh implemented in the psalm highlight the unity but also the differences between Yahweh as the ideal whole body' and the bodies of humankind and of nature. His voice can destroy nature (vv. 5-9) but can also provide strength and blessings to his vulnerable people (v. 11).

The rhetorical purpose underlying the implementation of the concept of the whole body as the ideal body in Psalm 29 is to glorify Yahweh because he is the 'ideal whole body'. All that form part of his 'ideal whole body' should glorify him accordingly. Thus, the rhetorical purpose of the psalm is to continuously strengthen the conviction of the cultic audience that Yahweh is superior. The bodily rhetoric was thus purposefully implemented within the psalm in order to illustrate the superiority of Yahweh and justify his glorification.

\section{Psalm 32}

Psalm 32 belongs to the genre of psalms of thanksgiving in which the author praises God for a specific deed that he has done in favour of the psalmist (Westermann 1980:25, 71). Psalm 32 is normally interpreted as one of the seven penitential prayers in the Psalter where the suppliant confesses sin. Weiser (1962:281) correctly classifies it as a thanksgiving psalm as it looks back upon the psalmist's penitence and upon the forgiveness of sin that has been obtained. It is important to examine the issue of confession and the metaphorising of the sick, un-whole body in order to understand the motives behind the praise within Psalm 32. For the illustrative purpose of this article, the emphasis will therefore be on the metaphorising of the un-whole body.

Through analysis of the inner texture (Robbins 1996a:7) of this psalm, we observe that a clear connection is made between the psalmist's bodily state of anguish and his sin. The psalmist also uses bodily rhetoric to illustrate his situation. This is evident through expressions such as 'my bones wasted away' (v. 3), 'your hand was heavy upon me' (v. 4) and 'my strength dried away' (v. 4).

The Sitz im Leben of the psalm is the cultic worship of ancient Israel, in which the consequences of sin and instruction against the non-confession of sin are emphasised. This provides greater insight into the function of the bodily rhetoric within the psalm. The psalmist's peers, who persecute him, are 
considered to be 'wicked' (v. 10). The psalmist views himself as part of all the godly people (v. 6) (Dahood 1965:195) and is devoted. He is persecuted due to his personal state of being un-whole and because he was part of the godly people.

Therefore, in Psalm 32, we find that the psalmist expresses a conversionist response to his world (Robbins 1996b:72) through his implementation of bodily rhetoric. Robbins (1996a) states:

[the] conversionist response is characterised by a view that the world is corrupt because people are corrupt. If people can be changed, the world will be changed. Salvation is considered available not through objective agencies but only by profound and supernaturally wrought transformation of the self. (p. 72)

The psalmist views himself part of the 'godly' (v. 6). This entails that he viewed himself as part of the people who have an intimate, trusting, loyal relationship with Yahweh. He also addresses the 'wicked' (v. 10), who is defined as a deceitful, stubborn person that denies Yahweh and persecutes the godly. The psalmist highlights the importance of the confession of sin through his description of his un-whole state and because of his body's telic demand for restoration. His conversionist response is directly related to his bodily experience.

The psalmist draws a direct correlation between his physical anguish and his spiritual state of iniquity. His un-whole state is manifested through his bodily state of anguish. Leder (1990:98) provides an explanation for the psalmist's state of anguish. Once the body becomes the focus of a negative thematic experience, it becomes the subject of a negative thematic state, which Leder (1990:84) calls dysappearance of the body. Leder (1990:25-28, 84) distinguishes between bodily disappearance and dys-appearance. Bodily disappearance is the state in which a person's body becomes part of one's background experience. Coetzee (2007:322) explains this state of disappearance in the following way: 'While listening to a concert, I am not aware of my body. All my senses are focussed on something outside my body.' However, bodily pain such as a headache brings the body itself in focus again and this negative thematic state is a state of bodily dys-appearance. Experiences which can lead to bodily dys-appearance include pain, illness and hunger (Leder 1990:84-86). Therefore, the physical state of anguish (v. 3), which the psalmist experiences, reflects bodily dysappearance.

However, Leder (1990:92) states that any form of social disassociation can also cause bodily dys-appearance, such as the experience of shyness or embarrassment (Leder 1990:93). He states:

My body is a profoundly social thing, arising out of experiences of the corporeality of other people and of their gaze directed back upon me. Am I fat or thin, beautiful or ugly, clumsy or agile? My self-understanding always involves the seeing of what others see in me. (p. 92)

In other words, my perception of my body is directly related to what I perceive other people to think of me. Therefore, if this social image of oneself becomes part of a negative thematic experience, one's body becomes subjected to bodily dys-appearance. Leder (1990:96) calls this social dysappearance. The psalmist states that, by confessing his sin, he acknowledged it (v. 5). Terrien explains this statement by arguing that, although Yahweh is omniscient and aware of the psalmist sins, the non-confession of his sin creates the 'poison of degeneracy' (Terrien 2003:293). Sin was not only seen as a violation against God but also against the 'neighbour' (Terrien 2003:292). The psalmist therefore emphasises the importance of the confession of $\sin$ in public. ${ }^{2}$

It is evident that the psalmist, due to his sin, experiences social dys-appearance when subjected to the judgement of Yahweh. The psalmist states that Yahweh's hand is heavy upon him (v.4), which metaphorically suggests that Yahweh's judgement is upon him. The psalmist also states that his bones are wasting away, implying that he is physically in an un-whole state (v. 3). The psalmist's bodily pain becomes part of the focal point of his experience. In such a state, it is characteristic of the human body to long and hope for relief, to develop a telic demand for recovery (Leder 1990:77).

The consequence of his social and physical un-wholeness, followed by recovery, culminates in the didactic mood in verses $8-10$ and his call for praise by the community in verse 11, a state in which wholeness is again experienced. This shows that sinning, resulting in un-wholeness, and forgiveness, resulting in wholeness, are socially connected. The psalmist, based on his own negative bodily experience, instructs his community to confess their sins in order to prevent the societal body from similar negative experiences of bodily dys-appearance (vv. 6-11).

Due to the dyadic ${ }^{3}$ nature of the body in the worldview of the ancient Israelites, the psalmist views himself as part of both the social body and Yahweh's body. Within this context, he encourages the societal body to confess their sins to Yahweh when in a state of un-wholeness in order for them to be healed and included in the body again.

Thus, it can be argued that the purpose of the psalmist's implementation of bodily rhetoric in Psalm 32 is, firstly, to address Yahweh. Yahweh's 'hand' struck the supplicant because of his initial refusal to confess his sin. This resulted in bodily pain and agony. For the psalmist, the key to becoming whole-bodied again was confessing his sin. Healing brought whole-bodiedness, resulting in thanksgiving and praise. Secondly, what he experienced personally is didactically transferred to the societal body: He encouraged the societal body to confess their sins as failure to do so could cause the individual and the societal bodies to be un-whole.

The rhetorical purpose behind the implementation of the concept of the whole body as the ideal body is to convince the psalmist's audience that a state of wholeness is the ideal state for cohesion with Yahweh's body and society.

\section{See Sheppard (1991:61-82) for the politics of public prayer.}

3.According to Malina (1993:62), the Mediterranean society was group or dyadic orientated and individualism did not take preference. The individual psalmist did thus not only have him or herself in mind when mourning, praising or praising within a given psalm but also had the heart of his community or household in mind. 


\section{Conclusion}

In summary, the following aspects of the thematic notion of bodily wholeness were found in the four chosen psalms:

- In Psalm 2, a royal psalm, the psalmist orients the nation of ancient Israel to a specific way of thinking about the kingdom (political) body. Yahweh as the ideal king, the ideal, whole, reigning body empowers his earthly king to maintain the wholeness of the political Israelite body. The maintenance of the boundaries of the kingdom body is necessary to maintain its wholeness. The king is therefore anointed by Yahweh to establish and protect these boundaries.

- In Psalm 6, an individual psalm of lament, the psalmist is considered to be un-whole or broken due to his illness and the attacks of his enemies (v. 7). The pain and suffering the psalmist experiences are due to his un-whole state, and only once his wholeness is restored by Yahweh will he be considered saved by him.

- In Psalm 29, Yahweh is worshipped because he is considered the one true 'whole body'. As such, all of creation, humankind and the heavenly beings should worship him as one body reflecting God's wholeness.

- In Psalm 32, a clear connection is made between the psalmist's un-whole bodily state and his anguish and sin. Only through confession of sin and the restoration of his wholeness can he be considered saved and forgiven of his sins. This also applies to the societal body of which the suppliant forms part.

This research reflects and emphasises the importance of a bodily reading of the psalms within the context of ancient Israelite's culture. Especially the notion of the whole body as the ideal body links the individual, society, heavenly bodies and God as one whole body whilst the un-whole, broken body (of the individual and society) refers to broken relationships and inherently demands future restoration and wholeness. The spheres of the cultic, liturgical tradition of Jewish worship, as by example illustrated by the four selected psalms from four different genres, directly relate to body rhetoric implemented by the authors.

\section{Acknowledgements Competing interests}

The authors declare that they have no financial or personal relationship(s) that may have inappropriately influenced them in writing this article.

\section{Authors' contributions}

This article summarises the conclusions of the M.A. dissertation of C.J.J.W. (University of Johannesburg), 'The rhetorical purpose of Israel's notion of the "whole body" as the ideal body in the psalms. A comparative study of selected psalms from four different genres', under supervision of J.H.C. (University of Johannesburg), Department of Religion Studies, 2012.

\section{References}

Berquist, J.L., 2002, Controlling corporeality: The body and the household in ancient Israel, University Press, New Brunswick, London.

Coetzee, J.H., 2007, 'Where humans and animals meet, folly can be sweet - Jonah's bodily experience of containment', Old Testament Essays 20(2), 320-332.

Dahood, M., 1965, Psalms 1-50, Doubleday, New York.

Davidson, R., 1998, The vitality of worship: A commentary on the Book of Psalms, Eerdmans, Grand Rapids.

Eaton, J., 2005, The Psalms: A historical and spiritual commentary with an introduction and new translation, Continuum, London.

Isherwood, L. \& Stuart, E., 1998, Introducing body theology, Sheffield Academic Press, Sheffield. PMid:9713006

Jobling, D., Day, P.L. \& Sheppard, G.T. (eds.), 1991, The Bible and the politics of exegesis. Essays in honour of Norman K. Gottwald on his sixty-fifth birthday, The Pilgrim Press, Cleveland.

Johnson, M., 1987, The body in the mind: The bodily basis of meaning, imagination and reason, The University of Chicago Press, Chicago.

Kraus, H.-J., 1972, Psalmen, 1 Teilband, Neukirchener Verlag, Neukirchen-Vluyn.

Kraus, H.-J., 1992, Theology of the Psalms, transl. Keith Crim, Fortress Press, Minneapolis.

Lawrence, L.J., 2005, Reading with anthropology: Exhibiting aspects of New Testament religion, Paternoster Press, Bletchley.

Leder, D., 1990, The absent body, The University of Chicago Press, Chicago.

Malina, B.J., 1993, The New Testament world: Insights from cultural anthropology, rev. edn., Westminster/Knox Press, Louisville.

Peels, H.G., 2001, 'The kingdom of God in the Old Testament', In die Skriflig 35(2), 173-190. http://dx.doi.org/10.4102/ids.v35i2.554

Robbins, V.K., 1996a, Exploring the texture of texts: A guide to socio-rhetorical interpretation, Trinity Press International, Valley Forge.

Robbins, V.K., 1996b, The tapestry of early Christian discourse, Routledge, London. http://dx.doi.org/10.4324/9780203438121

Schäder, J.-M., 2010, 'Understanding (the lack of) space in Psalm 47: 6 in light of its neighbouring psalms: A spatial reading of Psalms 46-48', Old Testament Essays 23(1), 139-160.

Schroer, S. \& Staubli, T., 2001, Body symbolism in the Bible, transl. L.M. Maloney, Liturgical Press, Collegeville.

Sheppard, G.T., 1991, 'Enemies" and the politics of prayer in the book of Psalms', in D. Jobling, P.L. Day \& G.T. Sheppard (eds.), The Bible and the politics of exegesis: Essays in honour of Norman K. Gottwald on his sixty-fifth birthday, pp. 60-82, The Pilgrim Press, Cleveland.

Terrien, S., 2003, The Psalms: Strophic structure and theological commentary, Eerdmans, Grand Rapids.

Weiser, A., 1962, The Psalms: A commentary, SCM Press, London.

Westermann, C., 1980, The Psalms: Structure, content and message, transl. R.D. Gehrke, Augsburg Publishing House, Minneapolis. 